\title{
A Percepção dos Discentes e Egressos dos Cursos de Gestão de uma Instituição de Ensino Superior Privada no Cariri acerca da Influência da Pesquisa Científica para seu Desempenho Profissional
}

\author{
Francisca Jucinária França ${ }^{1}$; Alyne Leite de Oliveira ${ }^{2}$; Hudson Josino Viana ${ }^{3}$; \\ Antonio Raniel Silva Lima ${ }^{4}$; Maria Patrícia de Alencar ${ }^{5}$
}

\begin{abstract}
Resumo: A pesquisa é responsável pela construção de conhecimento, através dela encontram-se respostas para as questões que surgem no dia-a-dia. As pessoas que estão inseridas no ensino superior, de uma forma ou de outra, acabam realizando pesquisas seja para conclusão de um curso, pós-graduação, mestrado ou doutorado, ou por satisfação pessoal, para agregar conhecimento e compreender melhor sobre um assunto, ou mesmo para contribuir para a melhoria da qualidade de vida daqueles que forem alvo do estudo. O presente trabalho tem como objetivo entender a percepção dos acadêmicos e egressos dos cursos de gestão de uma instituição de ensino superior privada no cariri sobre a pesquisa cientifica e a sua relação com seu desempenho profissional. Para investigar isso, utilizou um roteiro semiestruturado aplicado aos participantes selecionados por julgamento e foram apresentados por meio da análise de conteúdo. Ao final do estudo, foi perceptível nos relatos dos envolvidos não apenas a compreensão do que a pesquisa propõe, mas principalmente que ela contribui de maneira significativa, tanto na academia, quanto após, no desempenho da profissão.
\end{abstract}

Palavras Chave: Pesquisa Científica. Conhecimento. Desempenho Profissional. Acadêmicos. Egressos.

\section{The Perception of Students and Graduates of the Management Courses of a Private Higher Education Institution in the Cariri Region on the Influence of Scientific Research for its Professional Performance}

\begin{abstract}
The research is responsible for knowledge constrution, through it, find answers to the questions that arise in the day to day. The people who are inserted in higher education, one form or another, end up conducting research whether for completion of a course, postgraduate, master or doctorate, or for personal satisfaction, to aggregate knowledge and better understand a subject, or even to contribute with the quality of life of those who are the target of the study. The present work have like objective understand the perception of the academic and graduate students of management courses of a private higher education institution in Cariri on scientific research and its relation with their professional performance. For investigate this, we used a semi-structured script applied to participants selected by judgment and presented through content analysis. At the end of the study, it was noticeable in the report of those involved not only the understanding of what the research proposes, but mainly that it contributes significantly, both in academia and after, in the performance of the profession.
\end{abstract}

Keywords: Scientific research. Knowledge. Academics. Graduate.

${ }^{1}$ Graduada em Administração pelo Centro Universitário Doutor Leão Sampaio/UNILEÃO-jucinaria-franca@hotmail.com
2Especialista em Logística Empresarial, Orientadora da Graduação e Pós-Graduação da Faculdade Vale do Salgado/FVS e do
Centro Universitário Doutor Leão Sampaio/UNILEÂO, membro do Comitê de Ética em Pesquisa -
alyneleite@leaosampaio.edu.br
${ }^{3}$ Especialista em controladoria e auditoria, professor de Marketing da Faculdade Vale do Salgado/FVS e coordenador do curso
técnico em Administração da Escola Profissional Francisca de Albuquerque Moura/EPFAM-hudson.josino@gmail.com
${ }^{4}$ Professor da Graduação e Pós-Graduação da Faculdade Vale do Salgado/FVS e do Centro Universitário Doutor Leão
Sampaio/UNILEÃO, Mestrando em Administração de Empresas (UNIFOR) - raniel@leaosampaio.edu.br
${ }^{5}$ Graduada em Administração pelo Centro Universitário Doutor Leão Sampaio/UNILEÃO-patriciaalencar133@gmail.com

313 Id on Line Rev. Mult. Psic. V.12, N. 41, p. 313-337, 2018 - ISSN 1981-1179
Edição eletrônica em http://idonline.emnuvens.com.br/id 


\section{Introdução}

No cenário atual, onde muitas pessoas buscam ingressar em instituições de ensino superior (IES), outras concluindo suas atividades, durante esse percurso, passam por experiências de construir artigos, trabalhos de conclusão de curso (TCC), monografia, teses e etc, e a maioria delas, somente nesta etapa da vida é que são inseridas no mundo da pesquisa científica.

Demo (2011) destaca que o ato da pesquisa precisa ser inserido no ambiente cotidiano para desmitificar o conceito de que a pesquisa é uma atividade para pessoas e momentos especiais e específicos. Deve-se ser trabalhada de maneira natural, sobretudo é necessário compreender que ela perpassa diversos estágios, dos mais simples aos mais sofisticados, o que distingue o nível são os resultados obtidos.

A pesquisa científica ainda possui uma difícil aceitação por acadêmicos de todos os cursos, devido as dificuldades enfrentadas durante a sua construção, como também há receio por parte daqueles que vão iniciar uma produção científica, seja por falta de conhecimento e interesse na área ou por não ter esse hábito. Diante disso, percebe-se que essa questão causa ansiedade nos estudantes nos diversos âmbitos por ela perpassados, que vai desde a construção até a contribuição ou ligação que a mesma terá na sua vida profissional.

A partir disso, houve interesse de entender esse fenômeno, por isso o objetivo desse trabalho é investigar a percepção dos discentes e egressos dos cursos de gestão em uma instituição de ensino superior privada no cariri acerca da influência da pesquisa científica para seu desempenho profissional. Para alcançar esse objetivo foram traçados alguns objetivos específicos, tais como, discutir sobre a pesquisa científica no âmbito da gestão, compreender os benefícios e contribuições de uma pesquisa científica, indicar possíveis fatores que auxiliam no desempenho profissional, conhecer as dificuldades de construção da escrita científica e entender o papel da pesquisa na universidade.

Este estudo aborda três hipóteses, $1^{\circ}$ os participantes acreditam que a pesquisa científica é muito difícil, $2^{\circ}$ os envolvidos supõem que a pesquisa não influência no seu desempenho profissional, $3^{\circ}$ os participantes acham que a pesquisa deveria ser extinta do curso.

A relevância desse estudo no âmbito acadêmico se dá a partir do instante em que a mesma poderá destacar a importância e benefícios que traz a produção científica como também 
o conhecimento que se agrega no decorrer da graduação, principalmente para os estudantes dos cursos de gestão. Para a sociedade, ela pode contribuir de forma positiva, estimulando não só os acadêmicos, mas todos aqueles que tenham interesse de investigar sobre o tema. Além de servir de base para outros trabalhos, podem colaborar como fonte de informações para estudantes e demais interessados na área.

Para compreender melhor o assunto foi realizado inicialmente um levantamento bibliográfico acerca da pesquisa científica para conhecer as nuances que permeiam a construção da escrita científica e as suas contribuições para os acadêmicos. O estudo é classificado como pesquisa descritiva, de natureza básica, abordagem qualitativa, o instrumento utilizado para a obtenção de dados foi um roteiro de entrevista semiestruturado.

\section{Referencial Teórico}

Nesta seção será abordado a importância e os conceitos acerca da pesquisa cientifica, como também sobre a qualidade da pesquisa, seguido das causas e motivos que levam alguém a realizar uma pesquisa, e a relevância do ensino e da pesquisa na universidade, e finaliza com estudos sobre desempenho profissional.

\section{Pesquisa Científica}

Existe uma relação de interdependência entre o homem e a natureza, pois o ser humano precisa dela para viver e consequentemente está envolvido com tudo que acontece no mundo. Dessa forma, quando ocorre algo fora do normal o ser humano pode rejeitá-lo, simplesmente ignorar ou pode ser levado a refletir sobre o assunto, buscando assimilá-lo. As pessoas que tem a atitude de refletir são aquelas que possuem característica do espírito cientifico, ou seja, buscam soluções para os acontecimentos novos que tem diante de si (BASTOS e KELLER, 2014).

A elaboração do conhecimento científico é um processo de busca de respostas e através da pesquisa elaboram-se as explicações sobre a realidade em um determinado momento, e isso envolve algumas atividades, como a formulação do problema, ou seja, é o que se pretende 
pesquisar, onde se faz necessário delimitar esse problema. Em seguida é o planejamento, que deve conter os caminhos a serem percorridos pelo pesquisador para a obtenção de dados e também as condições necessárias para percorrer (MOROZ e GIANFALDONI, 2006).

Ainda se tratando do processo mencionado acima, outra etapa é a coleta de dados, esse é o momento em que são recolhidos os dados para serem analisados, e posteriormente coletados os dados são necessários que eles sejam organizados e analisados. No momento da análise de dados obtém-se a visão geral dos resultados obtidos. Após a análise realizada, vem a interpretação dos dados, que verifica se atingiu os objetivos pretendidos inicialmente com a pesquisa (MOROZ e GIANFALDONI, 2006).

A pesquisa cientifica é de suma importância para construção de conhecimento, pois surge de uma dúvida ou problema e através dos métodos científicos busca uma resposta ou solução (CERVO e BERVIAN, 2005). Complementam Marconi e Lakatos (2009) dizendo que é uma técnica formal, com método de pensamento reflexivo, que exige um tratamento cientifico, e é aplicada para conhecer a realidade ou descobrir verdades parciais, é necessário também saber o que vai procurar e o que se pretende alcançar.

Na concepção de Cruz e Ribeiro (2005) pesquisa é o mesmo que busca ou procura; buscar entender os fenômenos observáveis, onde se pode descrever sua constituição e como funciona, e tem como propósito ir ao encontro de soluções a questões propostas e tem como finalidade não apenas a coleta dos dados, mas sua compreensão. Incrementa Andrade (2010) que para a resolução desses problemas e questões é realizado um conjunto de procedimentos sistemáticos, baseado no raciocino lógico e métodos científicos.

Os autores Bastos e Keller (2014) conceituam que é uma investigação metódica que utiliza técnicas e procedimentos norteadores das ações para atingir o seu objetivo, que é de explanar particularidades do objeto em estudo. Eles ainda comentam sobre o que pode distinguir a pesquisa de um estudante e de um cientista, é a sua abrangência. Pois a pesquisa de um aluno tem o objetivo de repensar os caminhos já percorridos por ele.

Os trabalhos científicos surgiram a partir do momento que o homem no seu ambiente de trabalho, foi imposto a refletir sobre seu cotidiano, onde fez-se necessário expor suas ideias e amadurecê-las. Do mesmo modo acontece com os acadêmicos, a realização significa a síntese do esforço do pesquisador, o autor Matias-Pereira ainda destaca que a pesquisa é um meio parcial para a obtenção de títulos. Por isso, "ela pode ser aceita como a realização efetiva de 
uma investigação planejada e desenvolvida de acordo com as normas consagradas pela metodologia científica" (MATIAS-PEREIRA, 2016, p. 22).

\section{A Qualidade da Pesquisa}

Uma produção científica para ser útil, é necessário que tenha qualidade e que os resultados obtidos sejam disponibilizados para a sociedade interessada, é preciso estar exposto a qualquer momento. Por isso Hoppen e Meirelles (2005) explicam que a qualidade científica de uma pesquisa resulta, fundamentalmente, da sua validade externa, relacionado ao poder de generalizar os resultados e da sua validade interna para saber se efetivamente está sendo medido o que se deseja verificar.

Ainda se tratando da qualidade, Sordi e Tachizawa (2013) destacam dois aspectos que precisam ser abordados: ampla divulgação das informações da pesquisa ao público não acadêmico e permitir que o observador externo (leitor) possa identificar que as evidencias das questões iniciais leva as considerações finais da pesquisa.

A qualidade de uma pesquisa está de certa forma intimamente ligada a ética, pois para se obter uma boa pesquisa é necessário seguir os padrões éticos, como a segurança dos dados fornecidos, o respeito pelas ideias dos participantes, assegurar que a as informações relatadas de fato serão utilizadas para o objetivo proposto, e principalmente que a pesquisa não cause dano algum para os envolvidos, pois seria antiético fazer as pessoas investirem seu tempo em algo que no final do processo não resulte em um benefício para a sociedade, seja um resultado positivo ou negativo (FLICK, 2009).

Continuando com a ideia, a qualidade pode ser vista como um pré-requisito para a realização de uma pesquisa eticamente adequada, o que vai além do que definir critérios e padrões e simplesmente cumpri-los. Ainda pode ser entendida como uma série de decisões, pois ela é construída desde a formulação da pergunta da pesquisa até a escolha dos métodos apropriados para responder essa pergunta. Para melhor compreensão Flick (2009, p. 173) argumenta que "a qualidade pode e deve ser explicitada na forma como é definida, administrada nas etapas desse processo de decisão e produzida passa a passo".

Outro fator que influencia na qualidade de uma produção científica segundo Albuquerque (2009), é a má conduta do pesquisador durante o processo da pesquisa, 
especialmente no momento de construção da sua base teórica, pois o pesquisador pode se utilizar de ideias e conceitos de outras pessoas e de forma intencional ou inconsciente, não cita o autor ou faz referência de maneira inadequada e isso de uma forma ou de outra é considerado plágio, e consequentemente é um crime (ALBUQUERQUE,2009).

Essa má conduta pode exceder para a análise e interpretação dos dados, onde o pesquisador pode manipular os dados coletados para ir ao encontro de suas satisfações ou para ter um trabalho que cause impacto com seus resultados e esquecendo-se de buscar o objetivo proposto. Sendo assim, uma pesquisa que possui apenas cópia de outros trabalhos e manipulação dos resultados, pode-se dizer que não possui qualidade, por outro lado não dispõe de autenticidade e nem ao menos segue os padrões de ética (ALBUQUERQUE,2009).

\section{Entraves na Construção da Pesquisa Científica e na Divulgação dos Resultados}

Diante da sistematização da pesquisa e do alto nível de qualidade exigido para possuir rigor cientifico, as pessoas que realizam perpassam algumas dificuldades durante a sua construção. Podendo assim, destacar, segundo o estudo de Amaral (2010) que, o primeiro entrave é que o aluno chega no nível superior e não tem conhecimento sobre o que é de fato pesquisa, e muito menos quando vem acompanhado da expressão "científica", por isso causa esse trauma inicial de que pesquisa é, vulgarmente falando, um "bicho de sete cabeças". Assim, convém enfatizar essa falha no ensino básico e a responsabilidade das instituições em instruir adequadamente esses discentes.

Alguns fatores que intimidam a produção cientifica são a questão do tempo que é necessário para produzir uma investigação, a elaboração em si, o método que vai ser utilizado, como também a rígida normatização dos trabalhos e a base teórica, que é considerada difícil, isso mais uma vez remete ao ensino básico, pois os alunos estão acomodados com o ensino transmitido e não são estimulados a buscarem conhecimento fora da escola através das questões que permeiam em volta da mesma, e consequentemente, na faculdade sofrem esse impacto pois não tem prática, por isso demoram a assimilar a ideia (AMARAL, 2010; COSTA E SILVA, 2016).

O rigor é essencial na pesquisa para se obter um produto final de qualidade, assim outra dificuldade dos alunos na construção é em não ter uma formação inicial para realizar os passos 
peculiares da pesquisa como buscar ler, escrever, reescrever, classificar e se embasar teoricamente (GALIAZZI et al., 2003). De acordo com o estudo de Freitas et al. (2013), foram percebidas dificuldades como o quesito tempo, pois muitos alunos têm jornada de trabalho e além das atividades exigidas pela academia, pode-se citar também a parte da construção do referencial teórico, principalmente o acesso aos conteúdos e que sejam atualizados, outro que precisa ser evidenciado é uma boa comunicação com seus respectivos orientadores.

As pessoas envolvidas com pesquisa, além dos obstáculos perpassados na sua construção, ainda se deparam com entraves na divulgação dos resultados, podendo citar a adequação dos trabalhos as normas exigidas por cada meio de divulgação. Ainda assim, Costa e Silva $(2016$, p. 8) fomenta que "os pesquisadores com um grande volume de publicações que desfrutam do reconhecimento técnico dentro da comunidade científica, alcançam melhores colocações no mercado de trabalho, e divulgam o nome da instituição a qual estão vinculados".

A apresentação dos resultados de uma pesquisa se dá em dois níveis, inicialmente a comunicação cientifica, que é aquele direcionada para um público especifico que tem conhecimento acerca dos termos, conceitos empregados, são aquelas que frequentam congressos, eventos científicos; o outro nível é a divulgação científica, esse tipo é para as pessoas leigas cientificamente, que não conhecem os termos utilizados, onde é preciso fazer uma codificação para que eles possam compreender o assunto (BUENO, 2010).

Os pesquisadores destacam a demora que um trabalho leva para ser publicado, o que chega a ser de um ano após o recebimento do original pelo editor de um instrumento de divulgação (CAMPELLO et al., 2000). Outros impasses na divulgação relatados por alunos no estudo feito por Rodrigues et al. (2014) está relacionado a linguagem acessível utilizada no texto, que deve estar adequada ao público alvo, para que consiga assimilar e absorver o conhecimento, a veracidade dos fatos.

Brockington e Mesquita (2015) ressaltam que a divulgação cientifica é o elo entre a ciência e a sociedade, através dela é que o público leigo, através de jornais, tv, e internet tem acesso as informações científicas. Sendo assim, uma dificuldade que pode até comprometer a qualidade da divulgação é o fato de querer tornar o texto atrativo, onde o pesquisador faz o refinamento dos resultados para se adequar a linguagem do público leigo, e dessa forma o texto pode perder o rigor cientifico exigido. 


\section{O que leva à Construção da Produção Científica}

A pesquisa cientifica exige muito esforço mental, força de vontade e disponibilidade de tempo. Diante disso é válido destacar quais causas e motivos que levam um acadêmico ou docente a fazer uma pesquisa, já que ela requer muito do pesquisador. Conforme Medeiros (1986, p.51 apud OHIRA, 1998), um dos motivos pode ser o interesse pessoal, que por mais que tenha suas obrigações, regime de trabalho e outros comprometimentos, realiza trabalhos que vão ao encontro de suas satisfações.

Outra, das causas para realização da pesquisa, é a exigência da maioria das instituições de ensino superior (IES) na construção do Trabalho de Conclusão de Curso (TCC) - artigo ou monografia, nos cursos de graduação e pós-graduação, onde se torna uma oportunidade essencial para o graduando se tornar autor e pesquisador. Através da pesquisa, o universitário pode utilizar da interação entre teoria e prática, podendo assim quebrar antigos paradigmas observando as coisas sobre outra perspectiva, e principalmente, seja capaz de dar significado e credibilidade à sua graduação (RAMOS, 2009).

Na visão de Santos (2007) o que impulsiona o ato da pesquisa são as necessidades humanas básicas, pois é através delas que o indivíduo percebe a sensação de insatisfação no atual momento em que se encontram, onde se sente incompleto e precisa fazer algo para mudar. Contudo, ao detectar essa inquietação é necessária a ação da atividade intelectual intencional, ou seja, ter a iniciativa de pensar e transformar essas necessidades em problemas, como também ter a capacidade de questionar intencionalmente sobre ele com a intenção de aprimorá-lo, e posteriormente, utilizar métodos para gerar possíveis soluções para as questões levantadas.

Já outra causa evidenciada por Campello et al. (2000) está ligada as retribuições financeiras, tendo boas pesquisas pode-se concorrer a prêmios, a financiamento de fomento à pesquisa. É uma maneira de promoção na carreira para conseguir financiamentos e incentivos financeiros governamentais para desenvolver pesquisas, que se traduz na forma de prestigio individual.

\section{A Pesquisa Científica nas Universidades}


A educação no ensino superior é sustentada pelo tripé ensino, pesquisa e extensão. As universidades seja ela pública ou privada, precisam manter uma interação e mesmo grau de importância para cada um desses três elementos, para que possa dispor de um ensino de qualidade e formar profissionais competentes (ANDRADE e MOITA, 2009; ARAÚJO e BORGES, 2012).

É notório que em muitas universidades brasileiras apenas o quesito ensino é evidenciado, e a questão da pesquisa e extensão é um pouco esquecida. Sabido que é através da pesquisa que os universitários podem aprimorar a teoria, é onde busca e gera conhecimentos e assim pode-se obter um pensamento crítico, e através da extensão pode pôr em prática essa bagagem adquirida com a pesquisa e o ensino (ARAÚJO, BORGES, 2012).

O plano nacional de graduação (PNG, 2001) afirma a importância da pesquisa durante a graduação, pois é uma oportunidade para que o aluno se torne sujeito do seu aprendizado, e não seja apenas mais um ensinamento transmitido. Ainda fomenta o pensamento de que o acadêmico que inicia suas atividades cientificas durante sua graduação, certamente, terá uma formação mais sólida comparado aos que não participam de programas de iniciação cientifica (IC), existe essa necessidade por ser uma forma de preparar o aluno para os desafios do mundo (BRIDI et al., 2015).

O processo de ensino e aprendizagem no curso superior tem um diferencial do ensino básico, pois na universidade deve-se priorizar a busca pela construção do conhecimento e para obter isso é necessária e imprescindível à atividade da pesquisa. Na universidade o conhecimento deve ser construído pela experiência ativa do acadêmico, o professor precisa da prática da pesquisa para ensinar com qualidade, já o aluno precisa dela para aprender de forma eficaz (SEVERINO, 2016).

A pesquisa acadêmica é um exercício preparação para desenvolver o espírito de busca da indagação intelectual da pesquisa onde visa estimular a busca intelectual autônoma. Assim, o objetivo da pesquisa durante a fase acadêmica é que o discente possa aprender a problematizar as suas necessidades, solucionar ou indicar respostas adequadas. Faz-se necessário que esse profissional em formação possa ao final do curso superior ter aprendido a assimilar, criticar e aprimorar a informação em grau máximo (SANTOS, 2007).

\section{O Desempenho Profissional}


Diante das mudanças constantes no mundo, as pessoas ficam confusas sem saber qual caminho escolher para seguir na vida, o mesmo acontece com a vida profissional, visto que não é fácil decidir qual carreira trilhar. Dessa forma, quando se decide fazer uma vigem, uma festa ou mudança de residência, se faz necessário fazer um planejar antes, da mesma maneira com a carreira profissional, é necessário pensar o que é necessário fazer para se conseguir a carreira que se deseja.

Tajra e Santos (2015) destacam que o profissional é como uma empresa, pois para alcançar sucesso é necessário traçar metas, desafios e objetivos claros. Onde isso pode ser feito através do plano de ação, que é o detalhamento de atitudes pensadas e elaboradas, que mostre caminhos a serem seguidos, como também as estratégias e metas que possa atingir o que foi proposto.

Demo (2011) acrescenta que um profissional competente é além do que possuir um diploma, ele significa apenas o reconhecimento que se realizou algo. Não se pode parar, é necessário se renovar a todo o momento, se não outros passam na frente e o profissional pode sair do mercado. Ser um bom profissional é buscar sempre aprender, saber fazer e refazer, e mais que tudo, utilizar desses conhecimentos para enfrentar novos desafios, sobretudo não é aquele que apenas executa uma atividade, ele sabe pensar e estruturar sua profissão, resume-se no questionamento reconstrutivo.

Para verificar se um profissional tem um bom desempenho é necessário medir esse indicador, isso é feito através da avaliação de desempenho que é um instrumento que faz o levantamento de dados para a gestão de pessoas, os resultados obtidos são comprados com o que se espera e assim auxiliará a gerencia na tomada de decisão. Desse modo, as empresas devem detectar o nível de desempenho de seus colaboradores e suas necessidades e alinhar com suas expectativas, para que possa atingir os seus objetivos e por outro lado ter profissionais mais comprometidos, dedicados e consequentemente atingir êxito em toda a organização (CÂMARA et al., 2017).

Demo (2011) distingue três tipos de profissionais, no primeiro caso e mais comum, são aqueles que não tem a capacidade de inovar, simplesmente reproduzem o que se aprenderam na universidade. É o tipo que faz apenas o que mandam, nunca está preparado para enfrentar novos desafios, não supera questões inesperadas pois não sabem pensar. O segundo é enquadrado naqueles que são levados a pensar ou só faz algo para mudar uma situação apenas 
quando são impactados com um erro seu. O terceiro é o profissional autentico, capaz de pensar, de pesquisar e buscar soluções sem ser forçado, ele sempre refaz sua profissão, inova.

Se tratando da influência da pesquisa para o desempenho profissional, de acordo com estudos de Santos (2011), através da pesquisa se forma um profissional com senso crítico e reflexivo capaz de solucionar questões que se deparam no cotidiano da sua profissional, e a maior contribuição é a construção do conhecimento, como também contribui para a formação voltada para a academia. Ainda destaca uma questão que está sendo percebida que é a adequação do novo perfil de profissionais que tenha uma visão crítica e uma formação embasada na pesquisa.

O mercado de trabalho está cada vez mais competitivo, por isso apenas o diploma não é mais um diferencial. Sendo assim, exige do profissional além do conhecimento teórico uma prática embasada na produção de conhecimento, isso quando levada a questões trabalhistas e principalmente quando se tem o objetivo de seguir a careira acadêmica torna o currículo um aspecto decisório (COSTA e SILVA, 2016).

\section{Procedimentos Metodológicos}

Para delineamento da investigação, a abordagem caracterizou-se por ser de cunho qualitativo, pois segundo Flick (2009) através desse método pode-se avaliar e entender melhor as características e experiências do público interessado, como também facilita compreender o contexto da pesquisa levando em consideração os fatores sociais.

Ela é classificada como pesquisa básica pois o estudo tem como propósito contribuir para a ampliação do conhecimento científico e sugerir novas questões a serem investigadas. É considerada descritiva segundo seus objetivos, porque tem a finalidade de proporcionar maior familiaridade com o problema em questão, identificar relações entre variáveis, levantar opiniões e atitudes em uma população (GIL, 2010).

Foi realizada numa instituição de ensino superior que atua na região metropolitana do cariri há dezesseis anos e oferece treze cursos de graduação (Administração, Análise e Desenvolvimento de Sistemas, Biomedicina, Ciências Contábeis, Direito, Educação Física, Enfermagem, Fisioterapia, Gestão Comercial, Gestão de Recursos Humanos, Medicina Veterinária, Odontologia, Psicologia e Serviço Social). Atualmente conta mais de 8 mil alunos 
matriculados e o ensino é distribuído em quatro unidades, todas localizada na cidade de Juazeiro do Norte-Ceará. Porém, foi aplicada somente a alunos matriculados dos cursos de gestão: administração, analise e desenvolvimento de sistemas, gestão de recursos humanos, gestão comercial e ciências contábeis e egressos da instituição. A amostra foi selecionada por julgamento, tendo por critérios de inclusão: ser aluno ou já ter sido devidamente matriculado em um curso de gestão, já ter cursado a disciplina de metodologia, ter disponibilidade para participar da entrevista.

Depois de selecionados, foi elaborada uma entrevista individual. Foi escolhido esse método visto o que ele objetiva (FLICK, 2009). Realizou-se dez entrevistas, sendo três do curso de análise e desenvolvimento de sistemas, duas de cada um dos outros cursos, de administração, gestão de recursos humanos e ciências contábeis, e apenas uma de gestão comercial. É valido destacar que das dez entrevistas utilizou-se para este estudo apenas oito entrevistas para a análise, devido à saturação das respostas de alguns participantes.

Para a coleta, utilizou-se um roteiro de entrevista semiestruturado para obtenção dos dados, onde foram observados e analisados os discursos dos participantes, de forma individual e coletiva. É importante destacar que algumas entrevistas foram feitas pessoalmente e outras foram realizadas online, através da aplicativo whatsapp, devido a disponibilidade dos participantes. Após a coleta e análise, os dados apresentaram-se por meio da análise de conteúdo (AC). É valido ressaltar que o trabalho oferece risco mínimo e está de acordo com todas as normas da resolução 510/16, tendo sido aprovado pelo CEP (Comitê de Ética em Pesquisa).

\section{Análise e Discussão dos Resultados}

Tendo em vista o objetivo deste estudo, o conteúdo foi avaliado de forma individual e coletiva e analisado tomando por base as variáveis: percepção, conhecimento, pesquisa cientifica, desempenho profissional, entraves e dificuldades perpassadas.

Quadro 1: Percepção sobre pesquisa científica

\begin{tabular}{|c|l|l|c|}
\hline Sujeitos & Resposta & Recorte & Categoria \\
\hline ADM-1 & $\begin{array}{l}\text { Bom, a pesquisa científica é essencial independentemente do curso } \\
\text { de graduação em que se está inserido, pois se trata da busca por } \\
\text { conhecimento, daquilo que não se sabe e se deseja conhecer. }\end{array}$ & $\begin{array}{l}\text { Pesquisa científica é essencial } \\
\text { [...] busca por conhecimento. }\end{array}$ & Conhecimento \\
\hline
\end{tabular}




\begin{tabular}{|c|c|c|c|}
\hline ADM-2 & $\begin{array}{l}\text { Para mim, é um método, é um modo que a civilização humana } \\
\text { encontrou de normatizar, de dar um método para desenvolver o } \\
\text { conhecimento, para que ele possa se expandir. }\end{array}$ & $\begin{array}{l}\text { Um método de normatizar, para } \\
\text { desenvolver e expandir o } \\
\text { conhecimento. }\end{array}$ & Conhecimento \\
\hline ADS-1 & $\begin{array}{l}\text { A minha concepção a respeito da pesquisa é assim, que antes eu } \\
\text { tinha uma visão de estudo muito limitada e com a pesquisa } \\
\text { científica você mesmo pode levantar a sua própria tese a respeito } \\
\text { de determinado assunto. }\end{array}$ & $\begin{array}{l}\text { A pesquisa científica você pode } \\
\text { levantar a sua própria tese a } \\
\text { respeito de determinado } \\
\text { assunto. }\end{array}$ & $\begin{array}{l}\text { Conhecimento } \\
\text { Investigação }\end{array}$ \\
\hline ADS-2 & $\begin{array}{l}\text { Então quando você parte do princípio que uma pesquisa científica } \\
\text { vai ajudar a produzir novas ideias, se faz extremamente importante } \\
\text { (...), porque é um processo em que você vai investigar sobre um } \\
\text { determinado assunto, então querendo ou não você se torna um } \\
\text { cientista, você descobre um lado de Pesquisa, um lado de } \\
\text { investigação, (...) isso é sensacional, essa é a palavra certa (...), } \\
\text { desenvolve uma característica de como poder olhar com outros } \\
\text { olhos, descobre novas ideias, novas abordagens. }\end{array}$ & $\begin{array}{l}\text { Ajuda a produzir e descobrir } \\
\text { novas ideias, novas abordagens. } \\
\text { É um processo de investigação } \\
\text { sobre um determinado assunto, } \\
\text { A pesquisa é sensacional. }\end{array}$ & $\begin{array}{l}\text { Conhecimento } \\
\text { Descoberta } \\
\text { Investigação }\end{array}$ \\
\hline CTB-1 & $\begin{array}{l}\text { Ela é uma ferramenta que possibilita o pesquisador tomar } \\
\text { conhecimento mais aprofundado de um determinado objeto em } \\
\text { estudo, e assim, construir novas ideias acerca do assunto. }\end{array}$ & $\begin{array}{l}\text { Uma ferramenta que possibilita } \\
\text { aprofundar o conhecimento e } \\
\text { construir novas ideias. }\end{array}$ & Conhecimento \\
\hline GRH-1 & $\begin{array}{l}\text { A pesquisa dá ao aluno ciência e propriedade sobre o tema } \\
\text { pesquisado estimulando os mesmos a buscarem sempre mais } \\
\text { informações além de estimular na produção de conhecimento. }\end{array}$ & $\begin{array}{l}\text { A busca de } \begin{array}{l}\text { informação } \\
\text { estimular na } \\
\text { conhecimento. }\end{array}\end{array}$ & Conhecimento \\
\hline GRH-2 & $\begin{array}{l}\text { Acredito que a pesquisa científica é importante para aprimorar os } \\
\text { conhecimentos dos discentes e ampliar a capacidade de interação } \\
\text { do discente com a área de pesquisa escolhida. }\end{array}$ & $\begin{array}{l}\text { Aprimora os conhecimentos e } \\
\text { ampliar a interação entre uma } \\
\text { área escolhida. }\end{array}$ & Conhecimento \\
\hline GC-1 & $\begin{array}{l}\text { Ela está presente em nosso dia a dia. Mas é importante perceber } \\
\text { que a noção de ciência e de científico que circula cotidianamente } \\
\text { está ligada as ciências biológicas (...). A pesquisa científica e a } \\
\text { ciência estão para além destas representações. }\end{array}$ & $\begin{array}{l}\text { Está presente em nosso dia a } \\
\text { dia[...] A pesquisa científica e a } \\
\text { ciência estão para além destas } \\
\text { representações. }\end{array}$ & $\begin{array}{l}\text { Descoberta } \\
\text { Investigação }\end{array}$ \\
\hline
\end{tabular}

Fonte: Dados da pesquisa (2017)

Ao se analisar a percepção dos entrevistados acerca do proposto, observou-se em suas falas a incidência da categoria "busca por conhecimento", evidenciada por 07 dos participantes, confirmando o que mencionam Cervo e Bervian (2005) e Bastos e Keller (2014). Surgem ainda relatos onde se destacam "descoberta" e "investigação" (2 dos participantes respectivamente), reiterando o mencionado por Bastos e Keller (2014). Observa-se desse modo, uma compreensão "sensível" no tocante à percepção da "leitura" do cenário cotidiano como fomentador de novos achados, o que, para a á área de gestão se faz relevante ao se perceber que é a partir do olhar criterioso dos processos que surgem novos métodos e ferramentas que vão favorecer o desempenho organizacional, muitas vezes percebido apenas nas áreas relacionadas à saúde.

Quadro-2: A relevância da pesquisa durante a graduação 


\begin{tabular}{|c|c|c|c|}
\hline Sujeitos & Respostas & Recorte & Categoria \\
\hline ADM-1 & Sim, de extrema importância. & Extremamente importante. & É importante \\
\hline ADM-2 & $\begin{array}{l}\text { Sim. Ela é fundamental para os acadêmicos, porque a } \\
\text { academia é um local de pesquisa, onde se busca } \\
\text { conhecimento e onde se deve deixar conhecimento (...), } \\
\text { pois é o momento de se desenvolver, pois é na graduação } \\
\text { que a pessoa adquire conhecimento e a partir disso traça } \\
\text { seus caminhos (...) A academia gera esse despertar para } \\
\text { vida. }\end{array}$ & $\begin{array}{l}\text { A academia é um local de } \\
\text { pesquisa, onde se busca } \\
\text { conhecimento e onde se deve } \\
\text { deixar conhecimento[...]gera } \\
\text { esse despertar para vida. }\end{array}$ & $\begin{array}{l}\text { Recepção } \\
\text { conhecimento. }\end{array}$ \\
\hline ADS-1 & $\begin{array}{l}\text { É incontável a quantidade de vantagens que você pode } \\
\text { adquirir, porque na época da graduação é o momento que } \\
\text { você está tendo uma recepção de conhecimento, (...) você } \\
\text { entra em lugares que enriquece muito o seu conhecimento } \\
\text { a respeito de visão de mundo (...). }\end{array}$ & $\begin{array}{l}\text { Na graduação é o momento de } \\
\text { recepção e enriquecimento do } \\
\text { conhecimento na percepção } \\
\text { sobre mundo. }\end{array}$ & $\begin{array}{l}\text { Recepção } \\
\text { conhecimento. }\end{array}$ \\
\hline ADS-2 & $\begin{array}{l}\text { Ela se faz extremamente importante na graduação (...) } \\
\text { porque a pesquisa científica é aplicação na prática da ideia } \\
\text { que esse estudante teve a fim de produzir novos } \\
\text { conhecimentos, novas ideias a partir do experimento. (...) } \\
\text { ela tá se encaixando no mundo acadêmico, (...) quando } \\
\text { você pega um curso que não tem isso como obrigatório } \\
\text { você ver que são poucos estudantes que se interessam em } \\
\text { fazer uma pesquisa. }\end{array}$ & 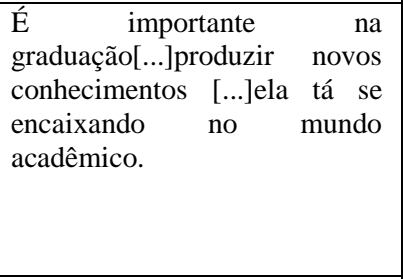 & Produzir conhecimento. \\
\hline CTB-1 & $\begin{array}{l}\text { Sim, através da pesquisa o graduando pode aprofundar em } \\
\text { um objeto de estudo e com isso ampliar os seus } \\
\text { conhecimentos. }\end{array}$ & $\begin{array}{l}\text { O graduando pode aprofundar } \\
{[\ldots] \text { e ampliar os seus }} \\
\text { conhecimentos. }\end{array}$ & Ampliar o conhecimento. \\
\hline GRH-1 & $\begin{array}{l}\text { Sim, a pesquisa é importante durante a realização da } \\
\text { graduação, o que me deixa bastante preocupado é o fato } \\
\text { das universidades apenas instigarem os seus alunos a } \\
\text { produzirem apenas no fim da graduação (...) é por isso que } \\
\text { pesquisas cientificas tais como TCC, monografia e outros } \\
\text { são tão temidos pelos alunos que estão prestes a se formar, } \\
\text { há necessidade de que as universidades introduzam a } \\
\text { técnica de escrever e pesquisar desde o início da } \\
\text { graduação, para que assim desperte dentro de cada } \\
\text { indivíduo o desejo de produzir e adquirir conhecimentos. }\end{array}$ & $\begin{array}{l}\text { [...] há necessidade de que as } \\
\text { universidades introduzam a } \\
\text { técnica de escrever e pesquisar } \\
\text { desde o início da graduação, } \\
\text { para que assim desperte dentro } \\
\text { de cada indivíduo o desejo de } \\
\text { produzir e adquirir } \\
\text { conhecimentos. }\end{array}$ & Produzir conhecimento. \\
\hline GRH-2 & $\begin{array}{l}\text { Sim, é de fundamental importância, pois aproxima o } \\
\text { discente com a sua área de interesse. }\end{array}$ & $\begin{array}{l}\text { [...]aproxima o discente com a } \\
\text { sua área de interesse. }\end{array}$ & $\begin{array}{l}\text { Aproxima a na área de } \\
\text { interesse. }\end{array}$ \\
\hline GC-1 & $\begin{array}{l}\text { A pesquisa ela não é importante só durante a graduação, } \\
\text { antes mesmo, ou seja, no ensino fundamental e médio, (...) } \\
\text { no ensino de base deve ser igual, em exigência do discente, } \\
\text { como se é num curso de graduação e pós-graduação, (...) } \\
\text { os discentes pesquisem suas comunidades, os processos } \\
\text { históricos e sociais, (...) a carreira acadêmica é uma das } \\
\text { opções do discente, mas aqueles que optam por uma } \\
\text { carreira profissional devem ter a consciência de que sua } \\
\text { formação é embasada cientificamente, (...) vai ter que se } \\
\text { deparar com a pesquisa, não tem pra onde correr. }\end{array}$ & 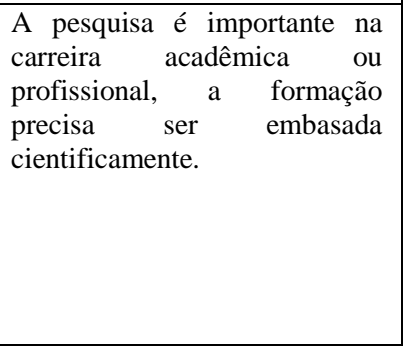 & $\begin{array}{l}\text { Formação embasada } \\
\text { cientificamente. }\end{array}$ \\
\hline
\end{tabular}

Fonte: Dados da pesquisa (2017)

O objetivo desta questão foi de compreender a relevância da pesquisa durante a graduação, onde se faz extremamente importante pois a academia é um momento de "recepção, produção e ampliação de conhecimento", citado por seis dos entrevistados, confirmando as ideias de Severino (2016) e Araújo e Borges (2012). Ainda cabe evidenciar que se faz necessária para que o discente possa ter uma formação mais sólida, "embasada cientificamente" e através da pesquisa haja uma aproximação na sua área de interesse (BRIDI et al., 2015). 
Percebe-se que a pesquisa deve começar a ser desenvolvida desde o ensino básico, pois é uma maneira de minimizar o impacto quando o aluno chegar no nível superior. Destaca-se também a responsabilidade das instituições de ensino superior, logo, precisam dar a mesma importância que o ensino tem, para a realização da pesquisa, pois em muitos casos, só se faz pesquisa no final de graduações e especializações, isso deveria ser aplicado com mais rigor e ser exigida desde o início do curso. (ANDRADE e MOITA, 2009; ARAÚJO e BORGES, 2012).

Quadro-3: Estímulos para a realização da pesquisa

\begin{tabular}{|c|c|c|c|}
\hline Sujeitos & Respostas & Recorte & Categoria \\
\hline ADM-1 & $\begin{array}{l}\text { Incentivo de professores e a busca por experiência e } \\
\text { conhecimento na área. }\end{array}$ & $\begin{array}{l}\text { Incentivo de professores } \mathrm{e} \\
\text { busca por experiência } \mathrm{e} \\
\text { conhecimento numa área. }\end{array}$ & $\begin{array}{l}\text { Incentivos de } \\
\text { professores. Interesse } \\
\text { em uma área. }\end{array}$ \\
\hline ADM-2 & $\begin{array}{l}\text { Já publiquei três trabalhos em anais, um capitulo de um livro, } \\
\text { tudo voltado pra minha área de interesse, o que levou a fazer } \\
\text { isso foi querer conhecer mais, saber o porquê das coisas. }\end{array}$ & $\begin{array}{l}\text { Querer conhecer mais uma } \\
\text { área. }\end{array}$ & Interesse em uma área. \\
\hline ADS-1 & $\begin{array}{l}\text { Assim o que me levou a fazer isso, primeiramente foi por } \\
\text { conta dos professores, que me incentivaram, que me } \\
\text { mostraram (..) alguns benefícios, como por exemplo, } \\
\text { conhecimento a respeito do tema, conhecimento a fundo, aí } \\
\text { a segunda foi justamente o meu interesse pelo conteúdo que } \\
\text { isso é bastante importante, quando você começa uma } \\
\text { pesquisa é interessante que você curta, que goste da } \\
\text { pesquisa, que goste de investigar, (...) porque a pesquisa } \\
\text { científica é muito enriquecedora para o seu conhecimento } \\
\text { então foi isso que me levou a fazer (...). }\end{array}$ & $\begin{array}{l}\text { Primeiramente foi por conta dos } \\
\text { professores }[\ldots] \text { e } \\
\text { interesse pessoal } \\
\text { conteúdo. }\end{array}$ & $\begin{array}{l}\text { Incentivos de } \\
\text { professores. Interesse } \\
\text { em uma área. }\end{array}$ \\
\hline ADS-2 & $\begin{array}{l}\text { O que me levou a fazer isso foi o fato de a princípio não saber } \\
\text { muito sobre o assunto (...), então eu acho que o que me levou, } \\
\text { acho não, tenho certeza, é justamente o fato da curiosidade, } \\
\text { você aprender sobre aquilo e não só aprender você colocar } \\
\text { em prática, que quando você faz uma pesquisa (...) você } \\
\text { percebe que aquilo lhe ajudou a ter mais conhecimento (...) } \\
\text { e por querer ajudar uma determinada parcela da sociedade. }\end{array}$ & $\begin{array}{l}\text { Curiosidade sobre um assunto } \\
{[\ldots] \text { e por querer ajudar a uma }} \\
\text { parcela da sociedade. }\end{array}$ & $\begin{array}{l}\text { Interesse numa área. } \\
\text { Desenvolvimento da } \\
\quad \text { sociedade. }\end{array}$ \\
\hline CTB-1 & $\begin{array}{l}\text { Durante a graduação realizei a pesquisa do trabalho de } \\
\text { conclusão de curso, e participei da elaboração de um livro } \\
\text { publicado pela UNILEÃO no dia do contador, sobre } \\
\text { questões do Exame de Suficiência, ambas as pesquisas foram } \\
\text { motivadas pela própria instituição. }\end{array}$ & $\begin{array}{lcc}{[\ldots] \quad \text { As }} & \text { pesquisas } & \text { foram } \\
\text { motivadas } & \text { pela } & \text { própria } \\
\text { instituição. } & & \end{array}$ & Incentivo da instituição. \\
\hline GRH-1 & $\begin{array}{l}\text { Durante a graduação nos últimos semestres cursamos uma } \\
\text { disciplina de Projeto Integrador, o objetivo da mesma é } \\
\text { escrever artigo sobre temas a fim, o meu desejo de escrever } \\
\text { floresceu no último semestre e desde então me sinto cada vez } \\
\text { mais entusiasmado em escrever e pesquisar. }\end{array}$ & 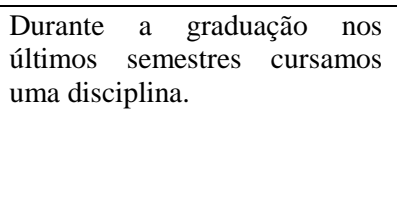 & Requisito da instituição. \\
\hline GRH-2 & $\begin{array}{l}\text { Sim, publiquei artigos tanto na faculdade quanto fora, e essa } \\
\text { iniciativa surgiu através do interesse em obter mais } \\
\text { conhecimentos sobre um determinado assunto, e assim poder } \\
\text { realizar uma pesquisa que possa contribuir para outros } \\
\text { também. }\end{array}$ & $\begin{array}{lrr}\text { [...]interesse em } & \text { obter } & \text { mais } \\
\text { conhecimentos } & \text { sobre } & \text { um } \\
\text { determinado } & & \text { assunto, } \\
\text { [...]contribuir } & \text { para } & \text { outros } \\
\text { também. } & & \end{array}$ & $\begin{array}{l}\text { Interesse numa área. } \\
\text { Desenvolvimento da } \\
\text { sociedade. }\end{array}$ \\
\hline GC-1 & $\begin{array}{l}\text { Tanto realizei como publiquei, muito para um estudante de } \\
\text { graduação tecnológica! O papel do professor neste momento } \\
\text { é fundamental. Comecei literalmente minha carreira }\end{array}$ & $\begin{array}{l}{[\ldots] \text { O papel do professor neste }} \\
\text { momento é fundamental }[\ldots] .\end{array}$ & Incentivo do professor. \\
\hline
\end{tabular}




\begin{tabular}{|l|l|l|l|}
\hline & $\begin{array}{l}\text { acadêmica quando cursei Metodologia do Trabalho } \\
\text { Científico (...). }\end{array}$ & & \\
\hline
\end{tabular}

Fonte: Dados da pesquisa (2017)

No tocante às causas ou motivos que levaram os participantes a realizarem pesquisas durante ou após a graduação. A maioria deles citaram duas causas, sendo que cinco deles afirmaram ter sido por "interesse" em conhecer mais sobre uma área que tem afinidade, logo constada o que relatou Medeiros (1986, p.51 apud OHIRA, 1998). Ainda foi citado "incentivo e requisito" da instituição de ensino para a realização de trabalhos científicos conforme Ramos (2009).

É válido evidenciar que "incentivo de professores" apareceu na fala de três entrevistados, onde cabe destacar a fundamental influencia que os professores têm na vida acadêmica do discente, por isso deve-se explorar mais esse fator para instigar a prática da pesquisa. Como também foi apontado como motivo o desejo de contribuir com o "desenvolvimento da sociedade" rompendo assim, o padrão de que só pesquisas na área da saúde traz benefícios para a população.

Quadro-4: Entraves e dificuldades durante a construção da pesquisa

\begin{tabular}{|c|c|c|c|}
\hline Sujeitos & Respostas & Recorte & Categoria \\
\hline ADM-1 & Encontrar pessoas dispostas a participar da pesquisa. & $\begin{array}{l}\text { Disponibilidade das pessoas } \\
\text { para participar. }\end{array}$ & $\begin{array}{l}\text { Disponibilidade do } \\
\text { público-alvo. }\end{array}$ \\
\hline ADM-2 & $\begin{array}{l}\text { A minha principal dificuldade foi no referencial teórico, (...) você } \\
\text { tem que ter lido muito a respeito pra poder transcrever, é } \\
\text { necessário que as informações tenha nexo e relevância pra se ter } \\
\text { uma produção de qualidade. Tem que conhecer e refletir sobre o } \\
\text { assunto, pra poder consolidar aquela ideia, então cada frase cada } \\
\text { parágrafo é minuciosamente pensado e fazer a conversa com os } \\
\text { autores. É necessário selecionar as informações e digeri-las, outra } \\
\text { dificuldade pra mim foi a falta de tempo. }\end{array}$ & $\begin{array}{l}\text { A minha dificuldade foi no } \\
\text { referencial teórico, [...] Outra } \\
\text { dificuldade é o quesito tempo. }\end{array}$ & $\begin{array}{l}\text { Construção do marco } \\
\text { teórico. } \\
\text { Falta de tempo. }\end{array}$ \\
\hline ADS-1 & $\begin{array}{l}\text { No início eu participei foi referências bibliográficas tava } \\
\text { complicado encontrar porque era um tema novo, (...) que tivesse } \\
\text { relevância no meu tema e na segunda foi assim, de início eu tive } \\
\text { que entender bem o tema, foi complicado, (...) porque tive que } \\
\text { compreender bem um tema para poder iniciar pesquisa. }\end{array}$ & $\begin{array}{lr}\text { Inicialmente } & \text { encontrar } \\
\text { referências } & \text { bibliográficas } \\
\text { relevantes e }[\ldots] & \text { compreender } \\
\text { bem tema. } & \end{array}$ & $\begin{array}{l}\text { Construção do marco } \\
\text { teórico. } \\
\text { Compreender o tema. }\end{array}$ \\
\hline ADS-2 & $\begin{array}{l}\text { A minha maior dificuldade foi realizar o filtro das bibliografias, } \\
\text { (...) a grande maioria das informações são repetidas, (...) e } \\
\text { apresentar essas informações e ao mesmo tempo colocar minha } \\
\text { opinião, acho que essa foi minha maior dificuldade por conta das } \\
\text { informações que eu tinha que eram muitas e até então eu não } \\
\text { conseguia filtrar de uma maneira que se tornasse atrativo, sabe? } \\
\text {...para o leitor. }\end{array}$ & $\begin{array}{l}\text { A minha maior dificuldade foi } \\
\text { realizar o filtro das } \\
\text { bibliografias, [...] a grande } \\
\text { maioria das informações são } \\
\text { repetidas, [...] de uma maneira } \\
\text { que se tornasse atrativo sabe } \\
\text { para o leitor. }\end{array}$ & $\begin{array}{l}\text { Construção do marco } \\
\text { teórico. } \\
\text { Texto atrativo. }\end{array}$ \\
\hline CTB-1 & $\begin{array}{l}\text { A principal dificuldade foi o desenvolvimento da pesquisa por } \\
\text { inteira, haja vista a falta de habitualidade em realizar tais } \\
\text { procedimentos distanciou a praticidade em interpretar e discorrer } \\
\text { sobre o objeto em estudo. }\end{array}$ & $\begin{array}{l}\text { A falta de habitualidade em } \\
\text { realizar tais procedimentos } \\
\text { distanciou a praticidade }[\ldots] .\end{array}$ & Falta de hábito. \\
\hline
\end{tabular}




\begin{tabular}{|c|c|c|c|}
\hline GRH-1 & $\begin{array}{l}\text { Uma das maiores dificuldades é conseguir organizar meus } \\
\text { horários, afinal além de estudante ainda tenho uma vida } \\
\text { profissional, as vezes me sentia sobrecarregado e em muitas vezes } \\
\text { psicologicamente cansado, o que acarretou em desmotivação e } \\
\text { vontade de trancar a cadeira, hoje eu me sinto mais tranquilo tanto } \\
\text { para escrever, pesquisar e até mesmo para debater sobre os temas } \\
\text { e possíveis novos temas para futuras pesquisas. }\end{array}$ & $\begin{array}{l}\text { É conseguir organizar meus } \\
\text { horários, afinal além de } \\
\text { estudante ainda tenho uma vida } \\
\text { profissional }[\ldots] \text {. }\end{array}$ & Falta de tempo. \\
\hline GRH-2 & $\begin{array}{l}\text { A minha pesquisa foi com vários pequenos comércios das } \\
\text { proximidades do horto, e a maior dificuldade encontrada foi a } \\
\text { visão restrita por parte do empregador diante das diversas } \\
\text { oportunidades de melhoria existentes que não são aproveitadas. }\end{array}$ & $\begin{array}{l}{[\ldots] \quad \text { maior dificuldade }} \\
\text { encontrada foi a visão restrita } \\
\text { por parte do empregador }[\ldots] .\end{array}$ & Visão Restrita. \\
\hline GC-1 & $\begin{array}{l}\text { Nas diversas pesquisas que já realizei, poderia dizer que no campo } \\
\text { qualitativo, uma das dificuldades (hoje não vejo como uma } \\
\text { DIFICULDADE) é em relação às entrevistas, principalmente } \\
\text { quando se faz uma pesquisa em gestão. Os/as gestores/as de } \\
\text { grandes empresas nunca estão, você marca, vai e não ele/ela não } \\
\text { está na empresa. Mas algo que é comum em toda a pesquisa, acho } \\
\text { que não se trata de dificuldade e sim dos desafios cotidianos da } \\
\text { pesquisa. }\end{array}$ & $\begin{array}{l}{[\ldots] \text { Os/as gestores/as de }} \\
\text { grandes empresas nunca estão, } \\
\text { você marca, vai e não ele/ela } \\
\text { não está na empresa [...]. }\end{array}$ & $\begin{array}{l}\text { Disponibilidade do } \\
\text { público-alvo. }\end{array}$ \\
\hline
\end{tabular}

Fonte: Dados da pesquisa (2017)

O objetivo desta questão, foi detectar quais as dificuldades observadas pelos entrevistados durante a realização da pesquisa científica. Onde pode-se observar que o principal impasse, foi durante a "construção do marco teórico" (citada 3 vezes), devido à falta de bibliografias atualizadas, a saturação das informações, e como também a dificuldade de filtrar as informações mais relevantes e não repetidas. E para isso faz se necessário uma reflexão acerca do assunto para ter uma base teórica com qualidade e sem plágio e que as informações tenham nexo, e sejam colocadas de maneira coerente e objetiva (ALBUQUERQUE, 2009; GALIAZZI et al., 2003; AMARAL, 2010; COSTA E SILVA, 2016).

Podendo destacar que foi apontando duas vezes, a questão de "falta de tempo" para conciliar regime de trabalho, vida acadêmica e pessoal e também a "disponibilidade do públicoalvo", relacionada a pessoas dispostas a começar e terminar a pesquisa confirmando o que relataram Freitas et al. (2013); Amaral (2010); Costa e Silva (2016). Não citado muitas vezes, porém é valido destacar a "falta de hábito" e tornar o "texto atrativo" segundo o estudo de Amaral (2010).

Quadro-5: Entraves no tocante a publicação dos resultados

\begin{tabular}{|l|l|l|l|}
\hline Sujeitos & Respostas & Recorte & Categoria \\
\hline
\end{tabular}




\begin{tabular}{|c|c|c|c|}
\hline ADM-1 & $\begin{array}{l}\text { Não houve entraves, exceto quanto a publicação, os sujeitos da } \\
\text { pesquisa geralmente se incomodam que os resultados sejam } \\
\text { divulgados, porém, publicar artigos ainda é algo bem complexo. }\end{array}$ & $\begin{array}{l}\text { Os sujeitos da pesquisa se } \\
\text { incomodam em divulgar os } \\
\text { resultados, [...] Ainda é algo } \\
\text { complexo. }\end{array}$ & $\begin{array}{l}\text { Desconforto dos } \\
\text { sujeitos. }\end{array}$ \\
\hline ADM-2 & $\begin{array}{l}\text { Para você publicar numa revista a1, a2, você tem que ter doutor no } \\
\text { mínimo, é muito difícil, o patamar exigido é o principal entrave, por } \\
\text { mais que seu trabalho esteja bom, se não tiver um doutor ou mestre } \\
\text { como autor envolvido seu trabalho não é nem avaliado. Infelizmente } \\
\text { você acaba dependendo de outras pessoas para submeter. }\end{array}$ & $\begin{array}{l}\text { O patamar exigido pelas revistas } \\
\text { [...]se não tiver um doutor ou } \\
\text { mestre como autor envolvido } \\
\text { seu trabalho não é nem avaliado } \\
{[\ldots] \text {... }}\end{array}$ & $\begin{array}{l}\text { Qualidade. } \\
\text { Pessoas } \\
\text { especialistas. }\end{array}$ \\
\hline ADS-1 & $\begin{array}{l}\text { Quanto a divulgação dos resultados, foi na questão da refinação desse } \\
\text { resultado para que chegasse numa variável comum, foi a principal } \\
\text { entrave que eu percebi, foi esse refinamento dos resultados, porque } \\
\text { você pega os dados brutos e refina para que se encaixe na sua } \\
\text { pesquisa, na sua investigação. }\end{array}$ & $\begin{array}{l}\text { A refinação dos resultados a } \\
\text { serem publicados. }\end{array}$ & $\begin{array}{l}\text { Refinamento dos } \\
\text { resultados. }\end{array}$ \\
\hline ADS-2 & $\begin{array}{l}\text { Eu costumo dizer que sempre tem aquelas pessoas que vão estar do } \\
\text { seu lado, vão ter opiniões iguais as suas, e infelizmente vai ter pessoas } \\
\text { que não vão concordar, né? }\end{array}$ & A aceitação da pesquisa. & $\begin{array}{l}\text { Relevância da } \\
\text { pesquisa. }\end{array}$ \\
\hline CTB-1 & $\begin{array}{l}\text { A divulgação dos resultados se tornou mais complexa em virtude da } \\
\text { necessidade de conciliar os resultados, com a pesquisa bibliográfica. }\end{array}$ & $\begin{array}{l}\text { [...] A necessidade de conciliar } \\
\text { os resultados, com a pesquisa } \\
\text { bibliográfica. }\end{array}$ & $\begin{array}{l}\text { Refinamento dos } \\
\text { resultados. }\end{array}$ \\
\hline GRH-1 & $\begin{array}{l}\text { Percebe-se que muitas vezes as pessoas não leem ou não são } \\
\text { verdadeiras com suas respostas, o que acaba prejudicando na } \\
\text { divulgação desses resultados. }\end{array}$ & $\begin{array}{l}\text { As pessoas não leem ou não são } \\
\text { verdadeiras com suas respostas } \\
{[\ldots . .]}\end{array}$ & $\begin{array}{l}\text { Veracidade dos } \\
\text { fatos. }\end{array}$ \\
\hline GRH-2 & $\begin{array}{l}\text { Na minha pesquisa o principal fator que mais me chamou a atenção } \\
\text { foi a visão restrita para as oportunidades, o medo de tentar algo novo } \\
\text { ou uma cultura muito tradicional e familiar que restringe as } \\
\text { inovações. }\end{array}$ & $\begin{array}{l}\text { Foi a visão restrita para as } \\
\text { oportunidades, o medo de tentar } \\
\text { algo novo ou uma cultura muito } \\
\text { tradicional e familiar. }\end{array}$ & $\begin{array}{l}\text { Desconforto dos } \\
\text { sujeitos. }\end{array}$ \\
\hline GC-1 & $\begin{array}{l}\text { No que tange a divulgação das pesquisas, um dos maiores entraves } \\
\text { atualmente, creio que tanto para estudantes como para professores- } \\
\text { pesquisadores são as questões de tempo e financeira. (...) e aí você } \\
\text { tem que se programar com antecedência, é todo um movimento, (...) } \\
\text { que são fundamentais para apresentação dos resultados e troca de } \\
\text { informações e parceria com outros pesquisadores. }\end{array}$ & $\begin{array}{l}{[\ldots] \text { Creio que tanto para }} \\
\text { estudantes como para } \\
\text { professores-pesquisadores são } \\
\text { as questões de tempo e } \\
\text { financeira, }[. . .] \text { e aí você tem que } \\
\text { se programar com antecedência, } \\
\text { é todo um movimento }[. . .] .\end{array}$ & $\begin{array}{l}\text { Tempo. } \\
\text { Questões } \\
\text { financeiras. }\end{array}$ \\
\hline
\end{tabular}

Fonte: Dados da pesquisa (2017)

No que diz respeito aos entraves no tocante a divulgação dos resultados da pesquisa, foram apresentadas categorias distintas, sendo elas apontadas por quatro dos participantes, o "refinamento dos resultados", a "qualidade" e "relevância da pesquisa, constando-se a ideia de Brockington e Mesquitz (2015). E em relação a "veracidade dos fatos", se realmente os envolvidos estão sendo sinceros no ato da pesquisa, segundo Rodrigues et al. (2014)

Cabe destacar, pois não foi citado por nenhum autor, no quesito de que há um "desconforto dos sujeitos" quando alerta que a pesquisa pode ser publicada. E também em relação a "questões financeiras" para a publicação em eventos científicos, congresso entre outros meios. Muitos pesquisadores até dispõe de pesquisa relevantes para a sociedade, porém 
por não dispor de um incentivo financeiro para arcar com as despesas, perdem a oportunidade de divulgar esses resultados que poderia contribuir de maneira significativa.

Quadro-6: Benefícios da produção científica na vida acadêmica e profissional

\begin{tabular}{|c|c|c|c|}
\hline Sujeitos & Respostas & Recorte & Categoria \\
\hline ADM-1 & $\begin{array}{l}\text { Experiência e conhecimento nas áreas abordadas, (...) pois tudo } \\
\text { aquilo que se estuda de forma aprofundada acaba inevitavelmente } \\
\text { sendo inserido no nosso desempenho profissional. }\end{array}$ & $\begin{array}{l}\text { Experiência e conhecimento } \\
\text { nas áreas abordadas [...] que } \\
\text { pode ser inserido no ambiente } \\
\text { profissional. }\end{array}$ & $\begin{array}{l}\text { Conhecimento em } \\
\text { uma área. } \\
\text { Melhor } \\
\text { desempenho. }\end{array}$ \\
\hline ADM-2 & $\begin{array}{l}\text { A especialização, ter um conhecimento especifico sobre minha área } \\
\text { que eu domino, é isso, dominar um conhecimento, uma parte } \\
\text { daquilo que é um todo, conseguir compreender, analisar e saber que } \\
\text { você ainda tem muito a aprender, mais que você sabe um pouquinho } \\
\text { daquilo, é saber que pode chegar em um ciclo de pessoa que tem } \\
\text { interesse no mesmo assunto e você pode interagir com elas com } \\
\text { propriedade, essa é a melhor parte.(...) nas consultorias, que eu estou } \\
\text { começando como estagiário, consigo melhorar esse desempenho } \\
\text { através das pesquisas. }\end{array}$ & 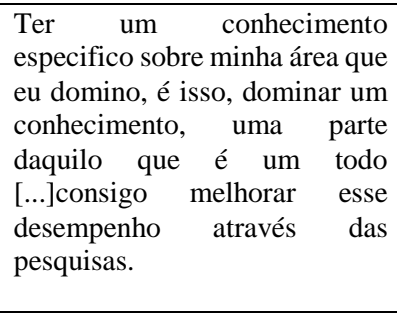 & $\begin{array}{l}\text { Conhecimento em } \\
\text { uma área. } \\
\text { Melhor } \\
\text { desempenho. }\end{array}$ \\
\hline ADS-1 & $\begin{array}{l}\text { As habilidades que eu adquirir, eu tinha um conhecimento da } \\
\text { produção, assim da elaboração de artigo, de trabalhos científicos, só } \\
\text { que a minha produção era eu posso considerar hoje muito amadora, } \\
\text { (...) então para questão da minha vida acadêmica trouxe diversos } \\
\text { benefícios em relação ao entrosamento com mais professores, em } \\
\text { relação a trazer títulos, (...) para concorrer a vaga de mestrados, que } \\
\text { é uma das coisas que eu quero muito futuramente, (...) só tende a } \\
\text { contribuir para sua vida profissional porque tudo que você aprende, } \\
\text { que vivencia no ambiente acadêmico, isso vai construindo uma } \\
\text { bagagem para que na sua vida profissional você possa ter ainda mais } \\
\text { qualidade, porque um acadêmico que desenvolve uma pesquisa } \\
\text { cientifica tende a ter mais habilidades do que aquelas pessoas que } \\
\text { não se interessa por pesquisa, habilidade de escrever, de perceber } \\
\text { (...). }\end{array}$ & $\begin{array}{l}\text { As habilidades que eu adquirir, } \\
{[\ldots . .] \text { em relação ao entrosamento }} \\
\text { com mais professores, em } \\
\text { relação a trazer títulos, [...]um } \\
\text { acadêmico que desenvolve uma } \\
\text { pesquisa cientifica tende a ter } \\
\text { mais habilidades. }\end{array}$ & $\begin{array}{l}\text { Desenvolveu } \\
\text { habilidades. } \\
\text { Formação sólida. }\end{array}$ \\
\hline ADS-2 & $\begin{array}{l}\text { Enquanto estudante vale ressaltar a qualidade de vida intelectual, } \\
\text { (...) você vai aprendendo ao longo desses processos, então a } \\
\text { qualidade da sua vida intelectual ela tende a subir de nível uma vez } \\
\text { que a pesquisa científica ele segue passos, segue processos e que } \\
\text { requer mais atenção requer mais do estudante, entendeu? você } \\
\text { aprende a selecionar e analisar informações ao mesmo tempo que } \\
\text { você tem que testar essas informações e ainda no final você relatar } \\
\text { esses resultados, (...) você se torna um cientista entre aspas pode-se } \\
\text { dizer, (...) enquanto profissional pode se dizer que você tem um } \\
\text { destaque, se for comparar uma pessoa que já fez pesquisas com uma } \\
\text { que não realizou, a pessoa que está avaliando com certeza vai } \\
\text { perceber que você tem uma habilidade a mais que seus concorrente, } \\
\text { (...) porque no mundo profissional, que tem mais habilidade } \\
\text { significa que é mais competente, (...) é um diferencial no seu } \\
\text { currículo, no seu lattes. }\end{array}$ & $\begin{array}{l}\text { Enquanto estudante vale } \\
\text { ressaltar a qualidade de vida } \\
\text { intelectual, [...] enquanto } \\
\text { profissional pode se dizer que } \\
\text { você tem um destaque, se for } \\
\text { comparar uma pessoa que já fez } \\
\text { pesquisas com uma que não } \\
\text { realizou [...]porque no mundo } \\
\text { profissional, que tem mais } \\
\text { habilidade significa que é mais } \\
\text { competente, (...) é um } \\
\text { diferencial no seu currículo, no } \\
\text { seu lattes. }\end{array}$ & $\begin{array}{l}\text { Qualidade de vida } \\
\text { intelectual. } \\
\text { Formação solida. } \\
\text { Desenvolveu } \\
\text { habilidades. }\end{array}$ \\
\hline CTB-1 & $\begin{array}{l}\text { O maior benefício proporcionado foi a melhor percepção quanto a } \\
\text { importância dada a uma pesquisa cientifica e o quanto ela pode } \\
\text { contribuir para a construção do conhecimento. (...) toda pesquisa } \\
\text { contribui e muito de alguma forma mesmo que no futuro, para o } \\
\text { desempenho profissional, por possibilitar uma ampliação de } \\
\text { conhecimentos. }\end{array}$ & $\begin{array}{l}\text { A percepção a respeito da } \\
\text { pesquisa, a importância } \\
\text { ampliação com relação a } \\
\text { construção do conhecimento. }\end{array}$ & $\begin{array}{l}\text { Conhecimento em } \\
\text { uma área. } \\
\text { Melhor } \\
\text { desempenho. }\end{array}$ \\
\hline
\end{tabular}




\begin{tabular}{|c|c|c|c|}
\hline GRH-1 & $\begin{array}{l}\text { Escrever, pesquisar proporciona um horizonte de novas ideias, além } \\
\text { de expandir meus conhecimentos eu posso afirmar que tenho } \\
\text { propriedade sobre aquele assunto, é necessário claro estar sempre } \\
\text { estudando, pesquisando e se aprofundando, eu sinto que a pesquisa } \\
\text { cientifica me proporcionou ser mais crítico, conseguir conversar, } \\
\text { além de ampliar meu vocabulário. (...) na minha vida profissional, } \\
\text { meu plano de carreira estas pesquisas serão de extrema importância. }\end{array}$ & $\begin{array}{l}\text { Proporciona propriedade sobre } \\
\text { um assunto buscando sempre } \\
\text { aprimorando, além de ampliar o } \\
\text { vocabulário e ser crítico. } \\
\text { Contribuiu com o plano de } \\
\text { careira. }\end{array}$ & $\begin{array}{l}\text { Conhecimento em } \\
\text { uma área. } \\
\text { Formação sólida. }\end{array}$ \\
\hline GRH-2 & $\begin{array}{l}\text { A oportunidade de colocar em prática todos os conhecimentos } \\
\text { adquiridos ao longo da faculdade em uma pesquisa científica } \\
\text { proporcionou o amadurecimento profissional e pessoal quanto as } \\
\text { diversas opiniões e situações existentes e diferentes, ter um novo } \\
\text { olhar sobre o ramo trabalhado na pesquisa, e ampliou meus } \\
\text { conhecimentos acerca das empresas tradicionais na região. }\end{array}$ & $\begin{array}{l}\text { No acadêmico possibilitou a } \\
\text { aplicação dos conhecimentos na } \\
\text { pratica, no profissional auxiliou } \\
\text { nas situações atípicas. }\end{array}$ & $\begin{array}{l}\text { Conhecimento em } \\
\text { uma área. } \\
\text { Visão crítica. }\end{array}$ \\
\hline GC-1 & $\begin{array}{l}\text { Os benefícios são inúmeros, mas destaco as formas diferentes de } \\
\text { olhar para um objeto ou fenômeno que a pesquisa agrega. Você ver } \\
\text { o que não está presente, principalmente quando se observa as } \\
\text { questões sociais. }\end{array}$ & $\begin{array}{l}\text { Uma visão crítica a respeito de } \\
\text { um fenômeno rotineiro e das } \\
\text { questões sociais. }\end{array}$ & Visão crítica. \\
\hline
\end{tabular}

Fonte: Dados da pesquisa (2017)

No tocante aos benefícios da pesquisa no âmbito profissional, falaram da ampliação do "conhecimento em uma área" (citado 5 vezes) adquiridos com a pesquisa, e são aplicados no ambiente profissional (SANTOS, 2011). Os participantes desse estudo se enquadram no nível três dos profissionais competentes, conforme classifica Demo (2011). Como também duas vezes apareceu "visão crítica", tornaram se mais preparados para os desafios do mundo profissional (BRIDI et al., 2015; SANTOS, 2011)

Com a participação de programas iniciação cientifica (IC) os participantes apontaram duas vezes que "desenvolveram habilidades" que comparados a outros alunos, torna-se um diferencial, por isso tem uma "formação mais sólida" e consequentemente tem "melhor desempenho" profissional (ambos citado 3 vezes) (BRIDI et al., 2015; COSTA e SILVA, 2016). É valido destacar, mesmo apenas um participante ter relatado a qualidade de vida intelectual, essa é a principal contribuição afirmada por Santos (2007).

Quadro-7: Aspectos da pesquisa utilizados no âmbito profissional

\begin{tabular}{|c|l|l|l|}
\hline Sujeitos & Respostas & Recorte & Categoria \\
\hline ADM-1 & Sim. & Utiliza. & Utiliza. \\
\hline ADM-2 & $\begin{array}{l}\text { Querendo ou não para o meu âmbito profissional, através das } \\
\text { pesquisas já conseguir 6 prêmios relacionado a minha área de } \\
\text { estudo a sustentabilidade, educação e empreendedorismo. Me } \\
\text { trouxe várias oportunidades, e sei que ainda vai me ajudar } \\
\text { bastante para um futuro mestrado, doutorado, phd. }\end{array}$ & $\begin{array}{l}\text { Através das pesquisas já } \\
\text { conseguiu títulos na área de } \\
\text { atuaçaro, [...] e ajudará bastante } \\
\text { para um futuro mestrado, } \\
\text { doutorado, phd. }\end{array}$ & Reconhecimento. \\
\hline
\end{tabular}




\begin{tabular}{|c|c|c|c|}
\hline ADS-1 & $\begin{array}{l}\text { A iniciação científica me trouxe a questão de uma visão mais } \\
\text { direcionada, pois quando eu vou falar para uma determinada } \\
\text { quantidade de pessoas, aprendi que tudo que eu vou falar seja } \\
\text { de forma breve clara, então isso foi moldado em determinada } \\
\text { parte da construção da iniciação científica e principalmente na } \\
\text { a questão da apresentação da ideia que seja de forma breve e } \\
\text { clara que todo, todo mundo que esteja escutando consiga } \\
\text { entender o que eu estou falando, a partir da forma que eu me } \\
\text { expresso. }\end{array}$ & $\begin{array}{l}\text { Aprendi que tudo que eu vou falar } \\
\text { seja de forma breve clara }[\ldots] .\end{array}$ & Clareza e Objetividade. \\
\hline ADS-2 & $\begin{array}{l}\text { Os aspectos da pesquisa que você pode levar para vida } \\
\text { profissional, é que você aprende a buscar conhecimento, } \\
\text { instinto de investigar, a analisar e observar mais de maneira } \\
\text { critica as coisas, aprende a organizar e filtrar as informações } \\
\text { importantes e também a saber as colocar numa ordem que } \\
\text { tenham sentido. }\end{array}$ & $\begin{array}{l}\text { [...]você aprende a buscar } \\
\text { conhecimento, instinto de } \\
\text { investigar, a analisar e observar } \\
\text { mais de maneira critica as coisas, } \\
\text { aprende a organizar e filtrar as } \\
\text { informações importantes [...]. }\end{array}$ & $\begin{array}{l}\text { Investigação, } \\
\text { Criticidade, } \\
\text { Posicionamento. }\end{array}$ \\
\hline CTB-1 & $\begin{array}{l}\text { A pesquisa científica desperta no pesquisador se este já não } \\
\text { tiver, à habitualidade em ler mais, buscar, querer se } \\
\text { aprofundar mais e se atualizar em algum objeto deparado no } \\
\text { ambiente de trabalho ou no meio profissional. }\end{array}$ & $\begin{array}{l}\text { [...] habitualidade em ler mais, } \\
\text { buscar, querer se aprofundar mais } \\
\text { e se atualizar em algum objeto } \\
\text { deparado no ambiente de trabalho } \\
\text { ou no meio profissional. }\end{array}$ & Investigação. \\
\hline GRH-1 & $\begin{array}{l}\text { A pesquisa me proporcionou novos conhecimentos, além de } \\
\text { habilidades que podem me proporcionar dentro do meu } \\
\text { ambiente de trabalho novas perspectivas, hoje me sinto mais } \\
\text { aberto a críticas, aberto ao diálogo, e disposto ao novo. }\end{array}$ & $\begin{array}{l}\text { [...] hoje me sinto mais aberto a } \\
\text { críticas, aberto ao diálogo, e } \\
\text { disposto ao novo. }\end{array}$ & $\begin{array}{l}\text { Disponibilidade, } \\
\text { Criticidade. }\end{array}$ \\
\hline GRH-2 & $\begin{array}{l}\text { Um dos aspectos enfatizados na pesquisa foi se atualizar } \\
\text { constantemente e se permitir algo novo para poder sobressair } \\
\text { diante dos demais concorrentes, e esse dilema sempre é } \\
\text { enfatizado no meu dia a dia: se permitir. }\end{array}$ & $\begin{array}{l}{[\ldots] \text { se permitir algo novo para }} \\
\text { poder sobressair diante dos demais } \\
\text { concorrentes }[\ldots] \text {. }\end{array}$ & Disponibilidade. \\
\hline GC-1 & $\begin{array}{l}\text { Todos, já que sou professor de Metodologia científica em uma } \\
\text { instituição de ensino superior. }\end{array}$ & $\begin{array}{l}\text { Sou professor de Metodologia } \\
\text { científica. }\end{array}$ & Ensino. \\
\hline
\end{tabular}

Fonte: Dados da pesquisa (2017)

Tendo em vista a conexão que a pesquisa tem com o âmbito profissional, observa-se nesse questionamento que além do nítido conhecimento que os entrevistados demonstram acerca da pesquisa, percebe-se o reconhecimento da influência da mesma em sua vida profissional. Esse fato é confirmado ao se perceber aspectos mencionados, tais como o desenvolvimento de habilidades que favorecem o desempenho de suas atividades, tais como: clareza, objetividade, criticidade, poder investigativo, ainda confirmando o que menciona Demo (2015). 


\section{Considerações Finais}

A pesquisa científica é essencial na construção do conhecimento, desde que sejam seguidos os passos e os métodos adequados, para que se tenha credibilidade e qualidade. $\mathrm{Na}$ universidade ela ainda não é tão evidenciada quanto a questão do ensino, mesmo sabendo que é um meio dos discentes ampliarem os seus conhecimentos, podendo testar suas ideias, e principalmente que seja ativo na construção do seu conhecimento sendo capaz de aumentar a qualidade intelectual autônoma.

Avaliando as hipóteses traçadas inicialmente, pôde-se confirmar a hipótese de que a pesquisa é considerada muito difícil devido a rigorosidade dos métodos empregados, porém isso pode ser minimizado conforme vai se exercitando. A segunda foi refutada porque os entrevistados afirmam que a pesquisa cientifica contribui de maneira significativa no seu desempenho profissional, devido à importância que foi dada a realização durante a sua graduação. A terceira também foi negada, pois a produção científica não deve ser extinta da academia, visto o que foi relatado pelos participantes ela deveria ser incentivada desde o início da graduação e não apenas ao final do curso como acontece na maioria dos cursos de gestão.

Portanto, tendo em vista o objetivo traçado inicialmente foi alcançado, sendo ele o de investigar a percepção dos discentes e egressos dos cursos de gestão em uma instituição de ensino superior privada no cariri acerca da influência da pesquisa científica para seu desempenho profissional. Além disso, foi perceptível, que a realização da pesquisa durante a graduação contribui de maneira significativa, tanto na academia, quanto após, no desempenho da profissão.

A realização deste estudo contribuiu de forma positiva para o pesquisador, podendo ampliar a visão a respeito de pesquisa cientifica, e dessa forma, sugere-se para futuros trabalhos para ser analisado a percepção de discentes dos cursos da área da saúde e possa fazer uma comparação com os da área de gestão, levando em consideração as variáveis, percepção a acerca da pesquisa, dificuldades superadas e principalmente a importância que é dada a cada área. 


\section{Referências}

ALBUQUERQUE, U. P. de. A qualidade das publicações científicas - considerações de um Editor de Área ao final do mandato. 2009. Versão eletrônica do artigo disponível em: <www.scielo.br/abb e http://www.botanica.org.br/acta/ojs>. Acesso em: 26 set. 2017.

AMARAL, R. do. As Contribuições da Pesquisa Científica na Formação Acadêmica. Identidade Científica, Presidente Prudente-SP, v. 1, n. 1, p. 64-74, jan./jun. 2010. Disponível em: <http://www.unoeste.br>. Acesso em: 08 out. 2017.

ANDRADE, M. M. de. Introdução Á Metodologia do Trabalho Científico: Elaboração de Trabalhos na Graduação. 10ª ed., São Paulo: Atlas, 2010.

ARAÚJO, J. B.: BORGES, M. F. Ensino, pesquisa e extensão na Educação Superior: processo histórico e perspectivas futuras. Revista digital, v.17, $\mathrm{n}^{\mathrm{o}}$ 172, 2012. Disponível em: <http://www.efdeportes.com>. Acesso em: 27 set. 2017.

BASTOS, C.L.; KELLER, V. Aprendendo a Aprender: introdução a metodologia cientifica. $28^{\text {a }}$ ed.- Petrópolis, RJ: Vozes, 2014.

BRIDI, J. C. A. A pesquisa nas universidades brasileiras: implicações e perspectivas. In: MASSI, L.; QUEIROZ, S. L. (orgs). Iniciação científica: aspectos históricos, organizacionais e formativos da atividade no ensino superior brasileiro [online]. São Paulo: Editora UNESP, p. $12-35,2015$.

BROCKINGTON, G.; MESQUITA, L. As Consequências da Má divulgação Científica, Revista de Biologia, 2016. Disponível em: <www.ib.usp.br.>. Acesso em: 10 out. 2017.

BUENO, W. C. Comunicação Científica e Divulgação Científica: Aproximações e Rupturas Conceituais. Inf. Inf., Londrina, v. 15, n. esp, p. 1 - 12, 2010.

CÂMARA, A. R. G. da, ENDERS, W. T., MEDEIROS, C. A. F., SILVA, L. M. T. da. Modelo de Valores Competitivos e suas Relações com o Desempenho Profissional numa Organização Hoteleira. Revista ADM, V. 11, No 2, p. 71-97, 2007.

CAMPELlO, B. S.; CENDÓN, B. V.; KREMER, J. M. Fontes de informação para pesquisadores e profissionais- Belo Horizonte: Ed. UFMG, 2000.

CERVO, A. L. e BERVIAN P. A. Metodologia Científica. $5^{\text {a }}$ Ed. São Paulo: Person Prentice Hall, 2005.

COSTA, L. R. da; SILVA, M. A. A. da. Dificuldades Vivenciadas na Elaboração de Artigos Científicos: Percepção de Discentes do Curso de Licenciatura em Matemática da Ufpe - Caa, 2016. Disponível em: 〈www.conedu.com.br〉. Acesso em: 15 out. 2017.

CRUZ, C.; RIBEIRO, U. Metodologia Científica: Teoria e Prática. $2^{\mathrm{a}}$ Ed., Rio de Janeiro, Axcel Books Brasil Editora, 2005. 
DEMO, P. Educar pela pesquisa. $9^{a}$ ed. Campinas, São Paulo: Autores Associados LTDA, 2011.

FLICK, U. Introdução à Pesquisa Qualitativa. Tradução: Joice Elias Costa, $3^{\circ}$ Ed.,- Porto Alegre: Artmed, 2009.

FLICK, U. Qualidade na Pesquisa Qualitativa. Tradução Roberto Cataldo Costa, Porto Alegre: Artmed, 2009.

FREITAS, S. M. B.; CHAVES, T. L.; CARVALHO, M. L. S.; COSTA, C. R. B.; MAYNART, W. H. da C. Dificuldades Vivenciadas na Construção do Tcc: Percepção de Estudantes Egressos de um Curso de Graduação em Enfermagem, Natal-RN, 2013.

GALIAZZI, M. do C.; MORAIS, R.; RAMOS, M. G. Educar pela Pesquisa: as resistências sinalizando o processo de profissionalização de professores. Educar, n. 21, p. 227-241. 2003. Editora UFPR, Curitiba, 2003.

GIL, A. C. Como Elaborar Projetos de Pesquisa, 5º ed., São Paulo: Atlas, 2010.

HOPPEN, N.; MEIRELLES, F. S. Sistemas de informação: um panorama da pesquisa cientifica entre 1990 e 2003. Revista De Administração De Empresa- RAE. v. 45, nº 1, jan./mar., 2005.

MARCONI, M. de A.; LAKATOS, E. M. Fundamentos De Metodologia Científica. $6^{\text {a }}$ Ed., 7reimpr., São Paulo 2009.

MATIAS-PEREIRA, J. Manual de metodologia da pesquisa científica, $4^{\mathrm{a}}$ ed., Atlas, 08/2016.

MOITA, F. M. G. da S.; ANDRADE, F. C. B. de. Ensino-pesquisa-extensão: um exercício de indissociabilidade na pós-graduação. Revista Brasileira de Educação v. 14 n. 41 maio/ago. 2009.

MOROZ, M.; GIANFALDONI, M. H. T. A. O Processo de pesquisa: Iniciação. $2^{a}$ ed., Brasilia: líber livro editora, 2006.

OHIRA, M. L. B. Por Que Fazer Pesquisa Na Universidade? Revista ACB: biblioteconomia em Santa Catarina, Florianópolis, V.3, N.3, 1998.

Percepção de Estudantes Egressos de um Curso de Graduação em Enfermagem, Natal-RN, 2013.

RAMOS, A. Metodologia da pesquisa científica: como uma monografia pode abrir o horizonte do conhecimento. Atlas, 03/2009. [Minha Biblioteca]. 
RODRIGUES, R. V.; NASCIMENTO, T. de S.; RODRIGUES, D. A. M. Conhecimentos e Dificuldades na Produção de Textos de Divulgação Científica por Alunos do Curso de Ciências Biológicas da Universidade Federal Do Ceará. Revista de SIENBIO, V. 10, N. 7, Ceará, 2014.

SANTOS, A. R. dos, Metodologia científica: a construção do conhecimento, $7^{\mathrm{a}}$ ed., revisada conforme a NBR 14724:2005.- Rio de Janeiro, 2007.

SANTOS, E. A. de. Produção Científica: Uma Análise de sua Contribuição na Formação Acadêmica e Profissional dos Discentes de Ciências Contábeis da UEFS. (Trabalho de Conclusão de Curso de Ciências Contábeis, outorgado pela Universidade Estadual de Feira de Santana-UEFS), 2011. Disponível em: <http://www.crcba.org.br/submissaodetrabalhos/arquivos/22092cb36f.pdf >. Acesso em: 12 out. 2017.

SEVERINO, A. J. Metodologia do trabalho científico. $24^{\mathrm{a}}$ ed. Ver. E atual - São Paulo: Cortez, 2016.

SORDI, J. O. de; TACHIZAWA, T. Introdução Da Tecnologia De Repositório Institucional: Oportunidade Para Repensar Aspectos De Qualidade Da Pesquisa Científica. REUNA, v.18, n.1, p. 73-88, Jan. - Mar., 2013.

TAJRA S. F.; SANTOS W. dos. Planejando a Carreira: Guia Prático Para o Desenvolvimento Pessoal e Profissional.

\section{Como citar este artigo (Formato ABNT):}

FRANÇA, Francisca Jucinária; OLIVEIRA, Alyne Leite de; VIANA, Hudson Josino; LIMA, Antonio Raniel Silva; ALENCAR, Maria Patrícia de Alencar. A Percepção dos Discentes e Egressos dos Cursos de Gestão de uma Instituição de Ensino Superior Privada no Cariri acerca da Influência da Pesquisa Científica para seu Desempenho Profissional. Id on Line Rev.Mult. Psic., 2018, vol.12, n.41, p.313-337. ISSN: 1981-1179.

Recebido: 14/06/2018

Aceito 25/06/2018 